\title{
Subspecies of Rosa nutkana and R. woodsii (Rosaceae) in Western North America
}

\author{
Walter H. Lewis \\ Washington University, Department of Biology, St. Louis, Missouri 63130, U.S.A., and \\ Missouri Botanical Garden, P.O. Box 299, St. Louis, Missouri 63166-0299, U.S.A. \\ Lewis@biology.wustl.edu
}

\section{Barbara Ertter}

University and Jepson Herbarium, University of California, 1001 Valley Life Science Bldg. 2456, Berkeley, California 94720-2465, U.S.A., and Research Associate, Missouri Botanical Garden, P.O. Box 299, St. Louis, Missouri 63166-0299, U.S.A. ertter@calmail.berkeley.edu

Abstract. Three subspecies of Rosa nutkana C. Presl and five of $R$. woodsii Lindley are recognized in western Canada and the United States, including four changes in combination and/or status: Rosa nutkana subsp. melina (Greene) W. H. Lewis \& Ertter, $R$. woodsii subsp. arizonica (Rydberg) W. H. Lewis \& Ertter, R. woodsii subsp. manca (Greene) W. H. Lewis \& Ertter, and R. woodsii subsp. gratissima (Greene) W. H. Lewis \& Ertter. Rosa nutkana subsp. melina and $R$. woodsii subsp. manca occur at high elevations of the southern Rocky Mountains and Colorado Plateau of Colorado and Utah with outlying populations in Arizona, Idaho, New Mexico, and Wyoming; $R$. woodsii subsp. arizonica is found at lower elevations of Arizona and the Colorado Plateau; and R. woodsii subsp. gratissima occurs in the mountains surrounding the Mojave Desert and southern Great Basin of California and Nevada, with its variety glabrata (Parish) D. Cole confined to the San Bernardino Mountains of California. Synonyms are provided for appropriate subspecies, 14 lectotypes and one neotype are designated here, and selected exsiccatae are given for newly recognized subspecies. The following names are lectotypified: Rosa bakeri Rydberg, nom. illeg., R. californica Chamisso \& Schlechtendal var. ultramontana S. Watson, $R$. deserta Lunell, $R$. fendleri Crépin, $R$. macounii Greene, $R$. maximiliani Nees, $R$. megalantha G. N. Jones, $R$. neomexicana Cockerell, $R$. nutkana var. alta Suksdorf, $R$. nutkana var. hispida Fernald, $R$. nutkana var. pallida Suksdorf, $R$. rainierensis G. N. Jones, $R$. spaldingii Crépin ex Rydberg, and R. subnuda Lunell. One neotype is designated: Rosa woodsii Lindley.

Key words: Rosa, Rosaceae, Western North America.

Rosa nutkana C. Presl and R. woodsii Lindley are two of the most widely distributed and variable species of Rosa L. in western Canada and the United States. Their diversity is particularly evident at higher elevations throughout the southern Rocky Mountains, including outlying mountainous peaks and ridges, and adjacent basins. In recognition of this diversity, both species have been divided into subspecies characterized by well-defined core morphological features within ecogeographic regions. Plants with intermediate characters may occur occasionally in transitional areas between such zones. Our treatment follows those of Piper (1906) for $R$. nutkana and Taylor and MacBryde (1978) for $R$. woodsii, who recognized $R$. nutkana subsp. macdougalii (Holzinger) Piper and $R$. woodsii subsp. ultramontana (S. Watson) R. L. Taylor \& MacBryde, respectively, as subspecies distinct from their autonyms. Both subspecies occur within the intermontane region between the Rocky Mountains to the east and the Cascade Mountains to the west, with the former primarily restricted to forested areas, while the latter is widespread in riparian sites in the sagebrush zone. In parallel within the high montane ecogeographic region of the southern Rocky Mountains and Colorado Plateau, the two species have also evolved distinct subspecies, which we name $R$. nutkana subsp. melina (Greene) W. H. Lewis \& Ertter and $R$. woodsii subsp. manca (Greene) W. H. Lewis \& Ertter, while another $R$. woodsii allied to subspecies manca, named subspecies arizonica (Rydberg) W. H. Lewis \& Ertter, occurs at lower elevations often in montane and plateau riparian habitats of Arizona and adjacent states to the north and east. The subspecies R. woodsii subsp. gratissima W. H. Lewis \& Ertter and its variety glabrata (Parish) D. Cole occur to the west in areas in and surrounding the Mojave Desert and southern Great Basin.

Infraspecific taxa in Rosa are used by us at three levels: subspecies, variety, and infrequently forma, 
although in this treatment only the first two ranks are used, with an emphasis on subspecies. Different subspecies occupy substantial ranges of a species in at least two distinct ecogeographic regions where populations possess distinct morphological characteristics. Such regions are often contiguous, which allows limited gene flow in transitional areas through hybridizing and backerossing. Physical and other barriers may exist, however, so that differing subspecific populations may be allopatric with consequent isolation and only limited or no gene exchange. Therefore, important features of these subspecific regions are their distinct geography and ecology. For example, with its wide geographic range within the Great Basin, sagebrush (Artemisia tridentata Nuttall) also has a broad ecological distribution from dry valley floors to mesic mountaintops, where precipitation is double or triple that of the valley. Three major subspecies (Shultz, 2006) associated with considerable adaptive radiation in both physiological and morphological traits relative to water availability that lead to successful adaptation to drought (Kolb \& Sperry, 1999) are found along this gradient. These differences also reflect genetic uniqueness of the subspecies based on common garden experiments. Moreover, ploidy levels differ between subspecies with diploids found at the highest level having moist soils, tetraploids at the lowest level with dry soils, and the intermediate subspecies with mixed diploid/tetraploid populations and an intermediate habitat. Undoubtedly, the evolution of these tetraploids is an example of the adaptive advantage of polyploids able to survive and expand under the harshest of drought conditions (Lewis, 1980). In summary, this is one of the most complete characterizations detailing subspecific successes of a species through physiological, anatomical, and cytogenetic adaptations, while confirming their distinctions based on morphologic, ecologic, and geographic data. This research further illustrates the evolutionary dynamics of populations within well-defined subspecies. Although R. mutkana and R. woodsii also illustrate clear subspecific distinctions based on morphologic, geographic, and ecologic (habitat) data and concomitant evolutionary lineages, experimental information comparable to that known for A. tridentata is not yel available.

Our treatment provides one example of the use of variety to characterize a cluster of populations having a relatively minor, but nevertheless distinctive, morphological variation within Iypical Rosa woodsii subsp. gratissima populations. This variant, called variety glabrata, having glabrous leaflets (abaxial), rachis/petioles, and stipules, contrasts with the typical variety with puberulent to pubescent leaflets (abaxial) and associated parts. Furthermore, variety glabrata is unique to a small geographic area of the subspecies in the San Bernardino Mountains of California. This example illustrates one of several possible instances whereby varietal rank is applicable in Rosa taxonomy.

The following synopsis of Rosa nutkana and $R$. woodsii consists of keys to subspecies, comprehensive synonymy, and representative exsiccatae of new subspecies and one variety. Fourteen lectolypes and one neotype are designated, including designations for those protologues that used both flowering and fruiting specimens as type, the flowering material collected usually in May or June and the fruiting material in September or October within a given year. Some are mounted separately and other mountings include flowering and fruiting material together; if the latter, they are readily distinguished by flowering and/or early hypanthium development and green leaflets or by fruiting (hips) and yellowish leaflets, while the other gatherings of each cited in the protologue are syntypes. Should lectotype and syntype be mounted on the same sheet, these are noted with pro parte (p.p.) followed by the information for either flower (fl) or fruit (fr). Such syntypes are provided in text following the nomenclature of appropriate subspecies.

1. Rosa nutkana C. Presl, Epim. Bot. 203. 1851. TYPE: Canada. British Columbia: Vancouver Island. Nootka Sound. Aug. 1791, T. P. X. Haenke s.n. (holotype, PR, PR photo at MO).

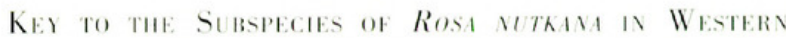
NorTh AMrRica

Ia. Shrubs short, 0.4-1.0(-1.5) m tall: fertile branches armed wilh curved or sometimes straight prickles, or rarely unarmed; sepal outer surfaces mostly stipitate-glandular; higher elevations of southern Rocky Mins. and adjacent peaks and ridges (2500$3800+\mathrm{m}) \ldots \ldots \ldots \ldots \ldots$. . . . . . . . . melina

1b. Shrubs taller, 1-3 m tall, occasionally shorter; fertile branches armed wilh straight or rarely curved prickles, or unarmed: sepal outer surfaces stipitate-glandular or eglandular; common at lower elevations (below $2500 \mathrm{~m}$ ).

2a. Ferlile branches nol dense, often wilh long inlernodes (to $6.5 \mathrm{~cm}$ ), commonly unarmed or with infrastipular prickles: leaflets usually eglandular below and singly serrated without gland lips; sepals commonly eglandular: intermontane between the Cascade and Rocky Mtns. . . . . . . . . . subsp. macdougalii

2b. Fertile branches often dense with shorter internodes, armed wilh paired infraslipular prickles, infrequently unarmed; leaflets often glandular below and commonly bi- or multiserrated and gland tipped; sepals commonly stipitate-glandular; Pacific coast from Alaska to northern California west of the Cascade Mıns................ subsp. mutkana 


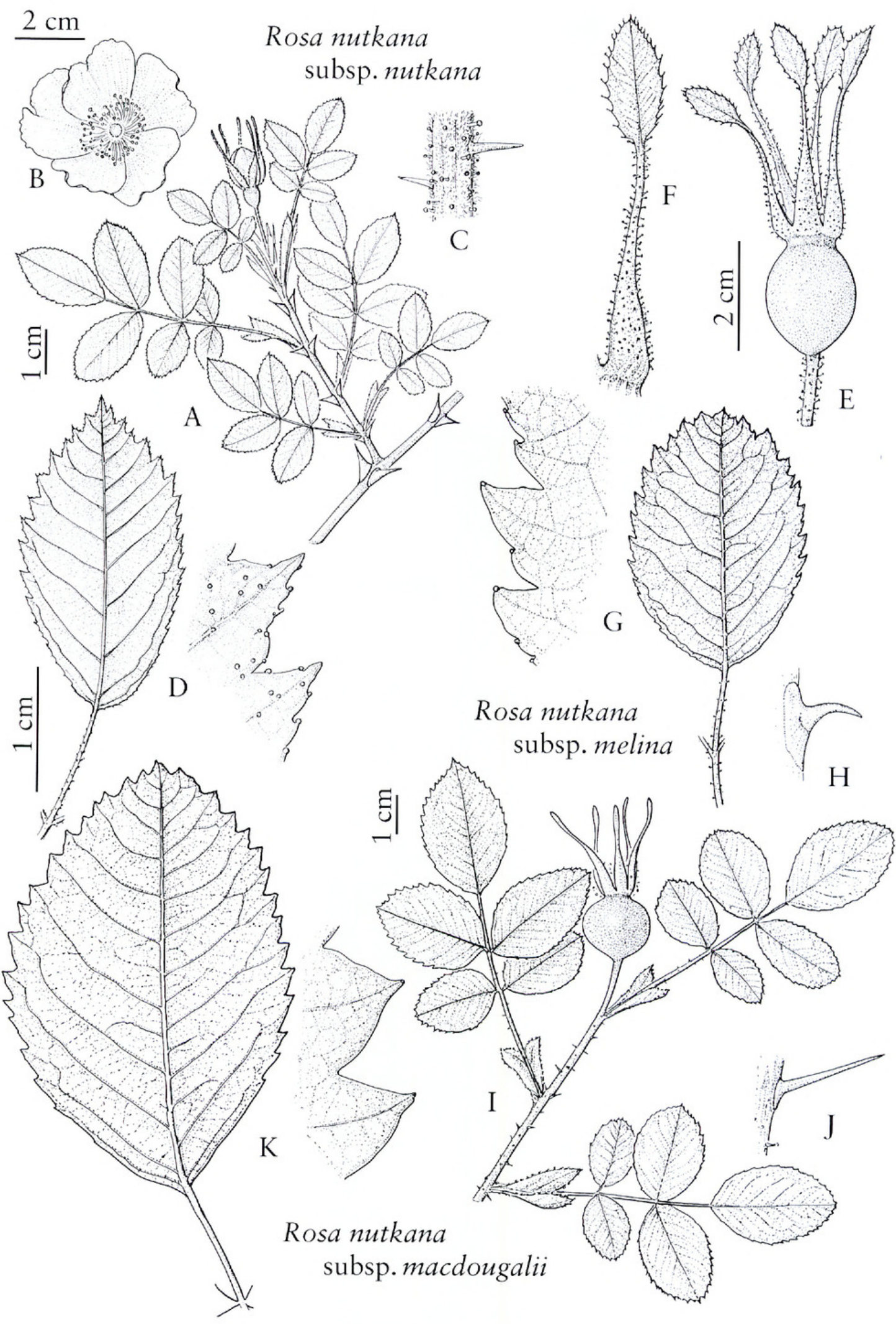

Figure 1. Rosa nutkana C. Presl subspecies. A-D. Subspecies nutkana. - A. Flowering branch. -B. Flower. -C. Upper branch detail. - D. Terminal leaflet with serrations. E-H. Subspecies melina (Greene) W. H. Lewis \& Ertter. -E. Hip with sepals. - F. Enlarged sepal. - G. Terminal leaflet with serrations. - H. Curved prickle single or paired. I-K. Subspecies macdougalii (Holzinger) Piper. - I. Fruiting branch. - J. Straight prickle. - K. Terminal leaflet with serrations. A-D drawn from Zeller 781 (MO); E-H drawn from Heil \& Mietty 20197 (SJNM); I-K drawn from Kirkwood 11180 (MO); all by J. Myers. 
1a. Rosa nutkana subsp. nutkana C. Presl. Figure $1 \mathrm{~A}-\mathrm{D}$.

Rosa aleutensis Crépin, Bull. Soc. Roy. Bot. Belgique 15: 48. 1876. TYPE: U.S.A. Alaska: Aleutians West Co., Unalaska Island (as "Ile d'Unalaschka"), 1846, P. K. N. S. Turczaninow s.n. (holotype, BR; isotype, LE not seen).

Rosa caryocarpa Douglas ex Crépin, Bull. Soc. Roy. Bot. Belgique 15: 39. 1876, nom. inval., pro syn. sub $R$. nutkana C. Presl.

Rosa durandii Crépin, Bull. Soc. Bot. France 22: 19. 1875. TYPE: U.S.A. Oregon: s. loc., 1871, E. Hall 146 (holotype, P-Durand herbarium; isotypes, BR [fragment]. F 455214, GH 32569, K, MO 1951280, NY $743773)$.

Rosa lyalliana Crépin, Bull. Soc. Roy. Bot. Belgique 16: 39. 1876, nom. inval., pro syn. sub $R$. nutkana C. Presl.

Rosa muriculata Greene, Leafl. Bot. Obs. Crit. 2: 263. 1912. Rosa nutkana var. muriculata (Greene) G. N. Jones, Madroño 3: 128. 1935. TYPE: U.S.A. Washington: Cowlitz Co., near Woodland, 15 July 1898, F. V. Coville 705 (holotype, US 80003; isotype, NY 335710 [fragment]).

Rosa nutkana var. setosa G. N. Jones, Madroño 3: 129. 1935. Syn. nov. TYPE: U.S.A. Washington: Island Co., Rocky point near Deception Pass, Whidbey Island, 2 June 1934, G. N. Jones 4908 (holotype, WTU 15784).

Rosa caryocarpa was collected by David Douglas in 1825 along the banks of the Columbia River in either Oregon or Washington, U.S.A. Sheets bearing his writing are at BM and $\mathrm{K}$ (Herb. Bentham 1854). The name otherwise appears only in Crépin's (1876: 39) synonymy of $R$. nutkana.

As part of the Oregon Boundary Commission aclivities along the United States and Canada border from Montana to British Columbia, David Lyall collected material from Vancouver Island and the Lower Fraser River, British Columbia, which Crépin named Rosa lyalliana in his honor on sheets at BR and BM. The name was provided by Crépin (1876: 39) as a synonym of $R$. nutkana. This naming also highlighted the joint American/British survey of the Northwest from Montana to British Columbia during 1857-1861 when many plants and animals were collected (Lyall, 1863). Most, if not all, collections and documents made by Lyall and other British survey members were returned to London where they were widely dispersed (to GH in North America), while documentations and collections obtained by the American Commission over this entire period were essentially lost.

The West Coast Rosa nutkana subsp. nutkana ranges from coastal Alaska south to northem California generally west of the Cascade Mountains.

1b. Rosa nutkana C. Presl subsp. macdougalii (Holzinger) Piper, Contr. U.S. Natl. Herb. 11:
335. 1906. Rosa macdougalii Holzinger, Contr. U.S. Natl. Herb. 3: 223. 1895. TYPE: U.S.A. Idaho: Kootenai Co., canyons near Farmington Landing, S end of Lake Coeur d'Alene, 7 July 1892, J. H. Sandberg, D. T. MacDougal \& A. A. Heller 572 (holotype, US 239980; isotypes, A, BR, DS 106275, F 124416, MO 775326, NA, NY 335711 \& 415851, PH). Figure 1I-K.

Rosa anatonensis H. St. John, Fl. Southeast Wash. \& Idaho 206. 1937 (as "anatonesis"). TYPE: U.S.A. Washington: Asolin Co., SW of Anatone, 850 m, 30 May 1928, H. St. John \& R. Palmer 95.55 (hololype, WS 67719 . isolypes, CH 32553, NY 415907, UC 544889, US 1654731, WS $67864 \& 67865$, WTU 31915).

Rosa brownii Rydberg, Bull. Torrey Bol. Club 44: 70. 1917. TYPE: U.S.A. California: Siskiyou Co., $\mathrm{N}$ side of Mt. Shasta, 1524-2743 m, 11-16 June 1897, H. E. Brown 349 (hololype, NY 345434; isotypes, MO 1951258, NY 345435. US 299325).

Rosa caeruleimontana H. St. John, Fl. Southeast Wash. \& Idaho 207. 1937. TYPE: U.S.A. Washington: Asotin Co., Blue Mins., 15 June 1928, G. N. Jones 1892 (holotype, WS 67855; isotypes, BM, CAS, IIL. not seen, SIU not seen, UC 544888, WS 67856 \& 67857).

Rosa columbiana Rydberg, N. Amer. Fl. 22: 514. 1918. Syn. nov. TYPE: U.S.A. Idaho: Latah Co., valley of Little Pollatch River, 13 June 1892, J. H. Sandberg, D. T. MacDougal \& A. A. Heller 381 (holotype, NY 415921 ; isolype, MO 775380).

Rosa delitescens Greene, Leafl. Bot. Observ. Crit. 2: 265. 1912. Syn. nov. TYPE: U.S.A. Oregon: Jackson Co.. Siskiyou Mıns., 3 Sep. 1889, E. L. Greene s.n. (holotype. NDG 23506).

Rosa jonesii H. St. John, Fl. Southeast Wash. \& Idaho 207. 1937. TYPE: U.S.A. Washington: Latah Co., summit of Moscow Mın., 26 June 1928, H. St. John \& G. N. Jones 9621 (holotype, WS 67852; isotypes, F 821225, GH 32582, MIN 332732, P, RM 143117, UC 544890, US 1654699, WS 67851 \& 67853, WTU 31922).

Rosa macrocarpa Nuttall ex Rafinesque, Med. Bot. 2: 258. 1830, nom. illeg., non F. V. Mérat, Nouv. Fl. Env. Paris 190. 1812. Syn. nov. U.S.A. Oregon or Washington: Columbia River, s.d., Nutlall s.n. (holotype, GH).

Rosa megacarpa Nuttall ex Torrey \& A. Gray, Fl. N. Amer. I: 460, 1840, nom. inval., pro syn. sub $R$. fraxinifolia Borkhausen.

Rosa megalantha G. N. Jones, Proc. Biol. Soc. Wash. 41: 194. 1928. Rosa spaldingii var. alta G. N. Jones, Madroño 3: 132. 1935. Syn. nov. TYPE: U.S.A. Washington: Spokane Co., Spokane, Lincoln Park, $600 \mathrm{~m}, 17$ June (fl) \& $10 \mathrm{Oct} .1927$ (fr), G. N. Jones 614 (lectotype, designated here, 17 June 1927 [fl]. WS 44430; isolypes, NY 743772, US 1924116. WS 43531. WTU 22024).

Rosa mutkana var. alta Suksdorf, Werdenda 1: 23. 1927. Syn. nov. TYPE: U.S.A. Washington: Klickitat Co., Bingen, 25 May \& 27 Oct. 1922, W. Suksdorf 10821 (lectolype, designated here, 27 Oct. 1922 [fr], MO 952023: isotypes, BM, GH 32597 , K p.p. [fr], MIN 584249 p.p. [fr], NY 415857 p.p. [fr], PH 654914 p.p. [fr]. UC 351907 p.p. [fr]. WS 121329 sheet 2, WTU 196772 p.p. $|\mathrm{fr}|)$.

Rosa nutkana var. hispida Fernald, Bot. Gaz. 19: 335. 1894. Rosa spaldingii var. hispida (Fernald) G. N. Jones. 
Madroño 3: 130. 1935. Syn. nov. TYPE: U.S.A. Montana: Rock Creek, 17 July 1880, S. Watson 124 (lectotype, designated here, GH 32593).

Rosa nutkana var. pallida Suksdorf, Werdenda 1: 23. 1927. Syn. nov. TYPE: U.S.A. Washington: Klickitat Co., Falcon Valley, 21 June \& 14 Oct. 1919, W. Suksdorf 10244 (lectotype, designated here, 21 June 1919 [fl], MO 952924; isotypes, BM, GH 32585 p.p. [fl], K p.p. [fl], NY 415858 p.p. [fl], PH 654932 p.p. [fl], UC 351877, US 1438016, WS 121268 p.p. [fl], WTU $196828 \& 196771$ p.p. [fl]).

Rosa rainierensis G. N. Jones, Univ. Wash. Publ. Biol. 7: 103, 174. 1938. TYPE: U.S.A. Washington: Lewis Co., Mt. Rainier, Goat Mtn., 1370 m, 11 July \& 19 Oct. 1897, O. D. Allen 292 (lectotype, designated here, 11 July 1897 [fl], WS 13052 p.p. [fl]; isotypes, MO 1951279 p.p. [fl], NY 415878 p.p. [fl], WTU 38311 p.p. [fl]).

Rosa spaldingii Crépin ex Rydberg, Flora Rocky Mts. 442. 1917. TYPE: U.S.A. Idaho (as Oregon): Clear Water (as Lapwai), Rev. Spalding s.n. (lectotype, designated here, $\mathrm{BR}$; isotypes, $\mathrm{BM}, \mathrm{GH}, \mathrm{K}, \mathrm{P}, \mathrm{PH}$ ).

Rosa spaldingii var. chelanensis G. N. Jones, Madroño 3: 133. 1935. Syn. nov. TYPE: U.S.A. Washington: Chelan Co., along Wenatchee River, near Cashmere, 23 Aug. 1927, G. N. Jones 1402 (holotype, WTU 356692; isotype, WTU 356693 not seen).

Rosa spaldingii var. parkeri $\mathrm{H}$. St. John, Fl. Southeast Wash. \& Idaho 210. 1937. Syn. nov. TYPE: U.S.A. Idaho: Latah Co., Grizzly Camp, 2 July 1922, C. S. Parker 503 (holotype, WS 47857; isotype, F).

Besides being illegitimate, publication of Rosa macrocarpa is certainly doubtful, for Rafinesque's description is limited to fruit the "size of pigeon egg, very good," and no subsequent description is known.

Rosa megacarpa was named by Nuttall for material he collected in Oregon (now Oregon or Washington) in open woods. Torrey and Gray (1840: 460) placed it in synonymy of $R$. fraxinifolia Borkhausen and mistakenly considered the collection to be of coastal origin. Nuttall's material at $\mathrm{K}$ is clearly $R$. nutkana from east of the Cascade Mountains (= subsp. macdougalii). It is most unfortunate that Torrey and Gray decided not to publish Nuttall's new species and description, for $R$. megacarpa would have predated C. Presl's $R$. nutkana by 11 years.

In his protologue, Jones provided two collections (both Jones 614) of Rosa megalantha: the flowering collection (17 June 1927) is designated lectotype in part because Jones noted in his protologue "conspicuous for its numerous, large, fragrant flowers," while the fruiting material was not mentioned. Further, numerous isolectotypes of flowering material have been distributed, while only two collections of fruiting material are known at one institution (syntype 10 Oct. 1927 [fr] at WS 43530 and 43532).

Of Suksdorf's (1082l) two collections of R. nutkana var. alta, fruiting material (12 Oct. 1922) is somewhat more widely distributed than flowering (25 May 1922); as both sets are diagnostically equivalent, the former is selected lectotype with its more numerous iso- lectotypes. Syntypes of 25 May (fl) are at GH 32596 , K p.p. (fl), MIN 584249 p.p. (fl), NY 415857 p.p. (fl), PH 654914 p.p. (fl), WS 121329 sheets 3 and 4, and WTU 196772 p.p. (fl).

Suksdorf 10244 is the basis of Rosa nutkana var. pallida; there is no particular reason for selecting the flowering collection (21 June 1919) lectotype except that it is available at MO, and only flowering material is mounted on this sheet. Syntypes of 14 Oct. 1919 (fr) are at GH 32585 p.p. (fr), K p.p. (fr), NY 415858 p.p. (fr), GH 654932 p.p. (fr), UC 351907 p.p. (fl), WS 121268 p.p. (fr), and WTU 196828 \& 196771 p.p. (fr).

Fernald cited three syntypes of Rosa nutkana var. hispida in his protologue, of which the earliest collection made by $\mathrm{S}$. Watson and deposited in his and Fernald's institutional herbarium $(\mathrm{GH})$ is selected lectotype, while C. V. Piper 1540 (Washington: Whitman Co., Pullman) represented by collections of 25 June 1893 (GH 32591) and September 1893 (not seen) are syntypes.

Flowering material of Rosa rainierensis at Jones's institutional herbarium is diagnostic and selected lectotype with numerous isolectotypes. Syntypes of 19 Oct. 1897 (fr) are at MO 1951279 p.p. (fr), NY 415878 p.p. (fr), WS 13052 p.p. (fr), and WTU 38311 p.p. (fr).

The selected lectotype of Rosa spaldingii at BR bears Crépin's annotation and is not complicated by having flowering and fruiting material mounted together as, for example, the isolectotype at BM.

The intermontane Rosa nutkana subsp. macdougalii occurs from central British Columbia east of the Cascade Mountains in Canada to northern California, east to Montana and Wyoming, and south to Colorado and Utah in the United States.

1c. Rosa nutkana C. Presl subsp. melina (Greene) W. H. Lewis \& Ertter, comb. et stat. nov. Basionym: Rosa melina Greene, Pittonia 4: 10. 1899. TYPE: U.S.A. Colorado: Montrose Co., Cerro Summit, near Cimarron, 30 Aug. 1896, E. L. Greene s.n. (holotype, NDG 23707). Figure $1 \mathrm{E}-\mathrm{H}$.

Rosa oreophila Rydberg, Bull. Torrey Bot. Club 31: 561. 1904. Syn. nov. TYPE: U.S.A. Colorado: Routt Co., Four-miles Hill, 2590 m, 22 July 1896, C. F. Baker s.n. (holotype, NY 415860; isotypes, MO 1951203, NDG 23560, NY 415862).

Rosa pandorana Greene ex Rydberg, Fl. Colorado 190-191. 1906. Syn. nov. TYPE: U.S.A. Colorado: San Miguel Co., region of Gunnison Watershed, Pandora, 10 Aug. 1901, C. F. Baker 751 (holotype, US 412379; isotypes, GH 32605, K, MIN 131154, MO 123831, NY 415866 , RM [2 sheets]).

Rosa underwoodii Rydberg, Bull. Torrey Bot. Club 31: 560. 1904. Syn. nov. TYPE: U.S.A. Colorado: Ouray Co., W 
of Ouray, above Box Cañon, 2300-2700 m, 8 Sep. 1904, L. M. Underwood \& A. D. Selby 122 (hololype. NY 429915).

When at US, E. I.. Greene named the C. F. Baker 751 sheet "Rosa pandorana Greene n. sp.," which was later published by P. A. Rydberg in the Flora of Colorado. This sheet is holotype with isotypes recorded at six herbaria. Later, Rydberg (1918: 513) reduced $R$. pandorana to synonymy of $R$. melina Greene $(=R$. nutkana subsp. melina $)$.

On sheets at NDG, Greene also annotated certain collections identifiable as Rosa nutiana subsp. melina using the names Rosa pudica (U.S.A. Colorado: Chaffee Co., Marshall Pass, 3310 m, 20 Aug. 1902. C. F. Bater 872) or Rosa stygia (U.S.A. Colorado: Gunnison Co., Black Cañon, 27 June 1901, C. F. Baker 263). These and other Baker collection sets are widely distributed.

Rosa nutkana subsp. melina is endemic to high mountains of Colorado, New Mexico, and Utah and rare in southeastern Idaho, Montana, and Wyoming, often on isolated peaks and ridges in or at edges of aspen, fir, spruce, and/or pine forests at elevations of $2500-3800+\mathrm{m}$. This distribution, to some degree. includes the subspecies in the Southern Rocky Mountain Floristic Element (McLaughlin, 1989), paralleling that of R. woodsii subsp. manca except for the Mogollon Rim component. In some regions, as in central and westem Colorado and southeastem Utah, R. mutkana subsp. melina is frequent and may be found growing near or with $R$. woodsii subsp. manca, but the subspecies also occurs at higher elevations beyond the others' range. Hybrids are possible but not expected even in mixed or nearby populations; this is because $R$. nutkana subsp. melina is hexaploid, while $R$. woodsii subsp. manca is diploid and because flowering of $R$. nutkana subsp. melina occurs before that of $R$. woodsii subsp. manca, although there can be an overlap of anthesis. No intermediate tetraploid hybrid has been found (Bruneau, Ertter \& Lewis, unpublished data).

Selected exsiccatae. U.S.A. Colorado: Archuleta Co.. S San Juan Wilderness Area, N side Fish Lake trail, $2870 \mathrm{~m}$. 19 July 2003, L. Lundquist \& G. Rink L2I6a (MO, SJNM): Garfield Co., to Little Trappers' Iake, 2870 m, 3 Aug. 1933. I. A. Hanna 1512 (MO); Cumnison Co.. Alpine rd. at milepost 15.7, II.1 mi. S of U.S. hwy. 50 , ca. 3080 m. II July 2006. J. L. Reveal 8777 (with C. R. Broome) (MARY. MO, NY): vic. of Mt. Carbon, 3000 m. 29 June 1910. W. W. Eggleston 5779 (US): La Plata Co., La Plata Canyon, beyond old la Plata City, 2875 m, 20 July 2005, W. H. Lewis \& V. Elvin-lewis 21000 (MO. MT. UC); Mesa Co.. 5 mi. NW of Mesa I ake, ca. 2440 m, 17 Aug. 1955, F. J. Hermann 12/84 (US); Mineral Co., FS rd. 634. 1.3 mi. E of jel. with FS rd. 633, 2575 m. 21 Aug. 2002, K. Heil \&. II. Mietty 20197 (SJNM); Montezumi
Co.. Mancos Canyon, 2 mi. above Aspen Guard station, 20 July 2005, $2985 \mathrm{~m}$. W. H. Lewis \& M. Elvin-Lewis 1.5992 (MO. MT. UC): Montrose Co., Uncomprahgre Plateau, head of Red Canyon, 2865 m. 7 Aug. 2004, B. Ertter 18464 et al. (MO. UC): Rio Grande Co.. FS rd. 667, ca. 7 mi. SWl of MeCormick cabin. 3170 m, 24 July 1996. K. Heil 10397 (SJNM): San Miguel Co., near Trout Lake, 3000 m. 16 Aug. 1924. E. B. Payson \& L. B. Payson 4/H (GH. MO, UC).

Idaho: Cassia Co., Hereford Ranger Station, 2440 m, 7 June 1927, II. P. Collam 3022 (F). New Mexico: Taos Co.. Carson Forest. Apache Peak \& Spring. 3000 m. 23 Aug. 1923. W. W. Eggleston 19251 (US). Utah: Grand Co., Uinta Basin. 10 mi. E of Sunnyside near Willow Springs. $2910 \mathrm{~m}$. 11 July 1935. E. H. Graham 9580 (A. MO): San Juan Co.. Abajo Mins., N slope, 2590-335.5 m. I-2 July 1930, G. J. Goodman \&. C. L. Hitcheoch 1424 ( $\mathrm{MO})$.

2. Rosa woodsii Lindley, Ros. Monogr. 21. 1820. TYPE: U.S.A. (Nebraska-lowa to Montana, not Missouri): near Missouri River, seeds grown by J. Sabine, Roval Hort. Society; "cultiv. HHS 1825" on herb. collection of plant designated "type" five years following publication of species (neotype, designated here, CGE).

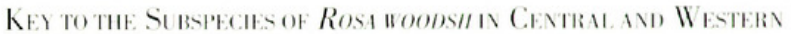
Nortir Auratca

la. Shrubs most frequently short. Iypically less than $1 \mathrm{~m}$, infrequently to $2 \mathrm{~m}$; fertile branches densely prickly of various sizes, rarely few or unarmed: terminal leaflets obovate, fewer ovate or elliptic: flowers 1 to 3 , rarely more: prairies and plains of central North America extending into the Rocky Mlns. and nearby Southwest.

2a. Prickles straight, rarely curved; sepals commonIy eglandular on outer surfaces or margins; rare or absent in highest elevations of Rocky Mtns. and oullying peaks and ridges. . . . . subsp. noodsii

2b. Prickles curved, rarely straight: sepals commonly slipitate-glandular on outer surfaces or margins: endemic to high elevations of Rocky Mıns. and oullying peaks and ridges. . . . . . . subsp. manca

1b. Shrubs most frequently tall, $\mathrm{I}-3(-5) \mathrm{m}$; flowering branches unarmed or with straight or curved prickles: terminal leaflets ovate to elliptic, fewer obovate: flowers 1 or 2 or corymbose and then 3 to 10(to 1.5): western North America including the far Southwesl.

3a. Prickles Iypically strongly curved. mostly short and stout, infrastipular paired; flowers I or 2 mosl common (to 6): sepals slipitateglandular on outer surfaces or margins, infrequently eglandular; low mountains and elevated riparian areas, primarily in northem Arizona and adjacent New Mexico, Colorado, Utah, and Vevada, with possible disjuncts as far north as southern Idaho ... subsp. arizonica

3h. Prickles straight or occasionally somewhat curved, absent or few to dense; flowers few, 3 most common or numerous (to 15); sepals eglandular or infrequently stipilate-glandular; intermontane between Cascade and Rocky Mıns. of British Columbia to southem Great 
Basin and mountains of Mojave Desert, and east to Rocky Mtns.

4a. Stems openly branching; prickles absent or sometimes scattered and/or infrastipular singly or paired, predominately straight; flowers commonly corymbose, 3 to 10(to 15); intermontane between Cascade and Rocky Mtns., common in Greal Basin . . . . . . . subsp. ultramontana

4h. Stems densely branching; prickles stout and often long, straight or curved, sometimes infrastipular and often dense and varying in size internodally; SW Great Basin, Mojave Desert and adjacent mountains . . . . . . . . . . substissima

2a. Rosa woodsii Lindley subsp. woodsii. Figure $2 \mathrm{~A}-\mathrm{D}$.

Rosa demareei E. J. Palmer, J. Arnold Arbor. I0: 36. 1929. Syn. nov. TYPE: U.S.A. Texas: Jeff Davis Co., Davis Mtns., Mt. Livermore, 4 June 1928, E. J. Palmer (with D. Demaree) 34351 (holotype, A 32568; isolypes, BH, F 678153, PH 690968, US 1439498).

Rosa deserta Lunell, Amer. Midl. Naturalist 2: 156. 1912. TYPE: U.S.A. North Dakota: Benson Co.. Pleasant Lake, 2 July (fl) \& 14 Aug. (fr) 1911, J. Lunell 592 (lectotype, designated here, 14 Aug. 1911 [fr]. MIN 245877: isotypes, MO 1011606 [fr]. NY 415925 [fr] \& 415926 [fr], PH 697763 [fr]).

Rosa fendleri Crépin, Bull. Soc. Roy. Bot. Belgique 15: 91. 1876. Rosa woodsii var. fendleri (Crépin) Rydberg in Bessey, Fl. Nebr., Rosales 21: 22. 1895. TYPE: U.S.A. New Mexico: vic. of Las Vegas, Aug. 1847, A. Fendler 210 (lectotype, designated here, BR; isolypes, BM, CGE, GH 32572 \& 32574 , K, MO 1949548, P. UC $711153)$.

Rosa fimbriatula Greene, Leafl. Bot. Observ. Crit. 2: 135. 1912. TYPE: U.S.A. Montana: rt. bank of Missouri River, 15 mi. below Round Butte, I Sep. 188x, L. F. Ward s.n. (holotype, US 46847; isolype, US 46848).

Rosa foliolosa [var.] leiocarpa Torrey in Frémont. Rep. 89. 1843. TYPE: U.S.A. Nebraska: Lower Platte River, J. C. Frémont s.n. (holotype, NY 415838).

Rosa hypoleuca Wooton \& Standley, Contr. U.S. Natl. Herb. 16: 131. 1913. TYPE: U.S.A. New Mexico: Sierra Co.. $S$ end of Black Range, near Kingston, I June 1904. $1980 \mathrm{~m}$, O. B. Metcalfe 940 (holotype, US 497843: isotype, NY 415845).

Rosa macounii Greene, Pittonia 4: 10. 1899. TYPE: Canada. Saskatchewan (as "Assiniboia"): Milk River, 7 July 1895, J. Macoun s.n., GSC 10533 (lectotype, designaled here, CAN 100023; isotypes, GH 32585, NDG 23690 ).

Rosa maximiliani Nees in Wied-Neuwied, Reise N. Amer. 2: 434. 1841. TYPE: U.S.A. South Dakota to NE Montana: vic. of Missouri River, A. P. Maximilian s.n. (lectotype, designated here, BR [Carl von Martius herb. 1444]).

Rosa naiadum Lunell, Amer. Midl. Naturalist 3: 139. 1913. TYPE: U.S.A. North Dakota: Ward Co., Minot, along Souris River, I July 1909, J. Lunell 596 (holotype, MIN 245872 ).

Rosa poetica Lunell. Amer. Midl. Naturalist. 3: 138. 1913. TYPE: U.S.A. North Dakota: Burleigh Co., banks of Missouri River, near Bismarck, 23 Aug. 1913, J. Lunell 593 (holotype, MIN 245883).
Rosa sandbergii Greene, Leafl. Bot. Observ. Crit. 2: 137. 1911. TYPE: U.S.A. Montana: Dawson Co., Colgate. near Glendive, 6 Sep. 1892, J. H. Sandberg, D. T. Macdougal \& A. A. Heller 1009 (holotype, US 239926: isotype, NY 415882).

Rosa standleyi Rydberg, N. Amer. FI. 22: 527. 1918. TYPE: U.S.A. New Mexico: San Miguel Co., near Pecos, 18 Aug. 1908, 2045 m, P. C. Standley 5043 (holotype, NY 4298991; isotypes, GH 32620, MO 123830).

Rosa subnuda Lunell, Amer. Midl. Naturalist 2: 153. 1912. TYPE: U.S.A. North Dakota: Benson Co., Butte, 25 June (fl) \& 28 Aug. 1911 [fr]. J. Lunell 596 (lectotype. designated here, 25 June 1911 [fl]. MIN 245873: isotypes, MIN 245874 [fl]. RM 156259 [fl]).

Rosa terrens Lunell, Amer. Midl. Naturalist 2: 151. 1912. Rosa woodsii var. terrens (Lunell) Breitung, Canad. Field-Naturalist 68: 82. 1954. Syn. nov. TYPE: U.S.A. North Dakota: Benson Co., Pleasant Lake, 14 Aug. 1911, J. Lunell 594 (holotype, MIN 245875 [sheet 1 of 2]; isotype, MIN 245875 [sheet 2 of 2]).

Fruiting material (14 Aug. 1911) of Rosa deserta is designated lectotype as it is diagnostic and isolectotypes are widely available; syntype (2 July 1911 [fl]) is at MIN 245858.

In his protologue, Crépin described Rosa fendleri based on a collection at B, which was destroved during World War II. Later in the protologue, he discussed finding Fendler 210 at both BM and K, the former described with some uncertainty due to variation from the Berlin material, while the $K$ collection was not discussed further, presumably because it was more similar to the original $B$ collection. It is diagnostic, and so the $\mathrm{K}$ specimen is chosen lectotype.

Rosa foliolosa [var.] leiocarpa (smooth hip) is not an eglandular hipped form of $R$. foliolosa Nuttall, which is not known from or near Nebraska. Rather, Torrey mistakenly described a new variety of $R$. woodsii that is typical of the species. In their protologue three years earlier, Torrey and Gray (1840: 460) extended the range of $R$. foliolosa, with a query, to eastern Florida. which is $R$. palustris Marshall. Clearly Nuttall, but not Torrey or Gray, had a correct concept of his new species, which is known only from south-central U.S.A.

In his protologue, Greene cited three syntypes of Rosa macounii, two collected in Assiniboia (Saskatchewan) and a third in Wyoming. Based on Rydberg's (1918: 525) selection of the type locality as Saskatchewan, and since these two were collected by Macoun and are diagnostic, the Milk River collection is selected lectotype where isolectotypes are known at both GH and NDG. Syntypes are from: CANADA. Saskatchewan: Moose Jaw, 13 Aug. 1895. J. Macoun s.n., GSC 10532 (CAN 100025); and U.S.A. Wyoming: Laramie Co., near Cheyenne, 24 June 1896, E. L. Greene s.n. (NDG 23692). Martin and Hutchins (1980: 928) reduced $R$. macounii to a variety of $R$. woodsii, but as the basionym was not provided it 


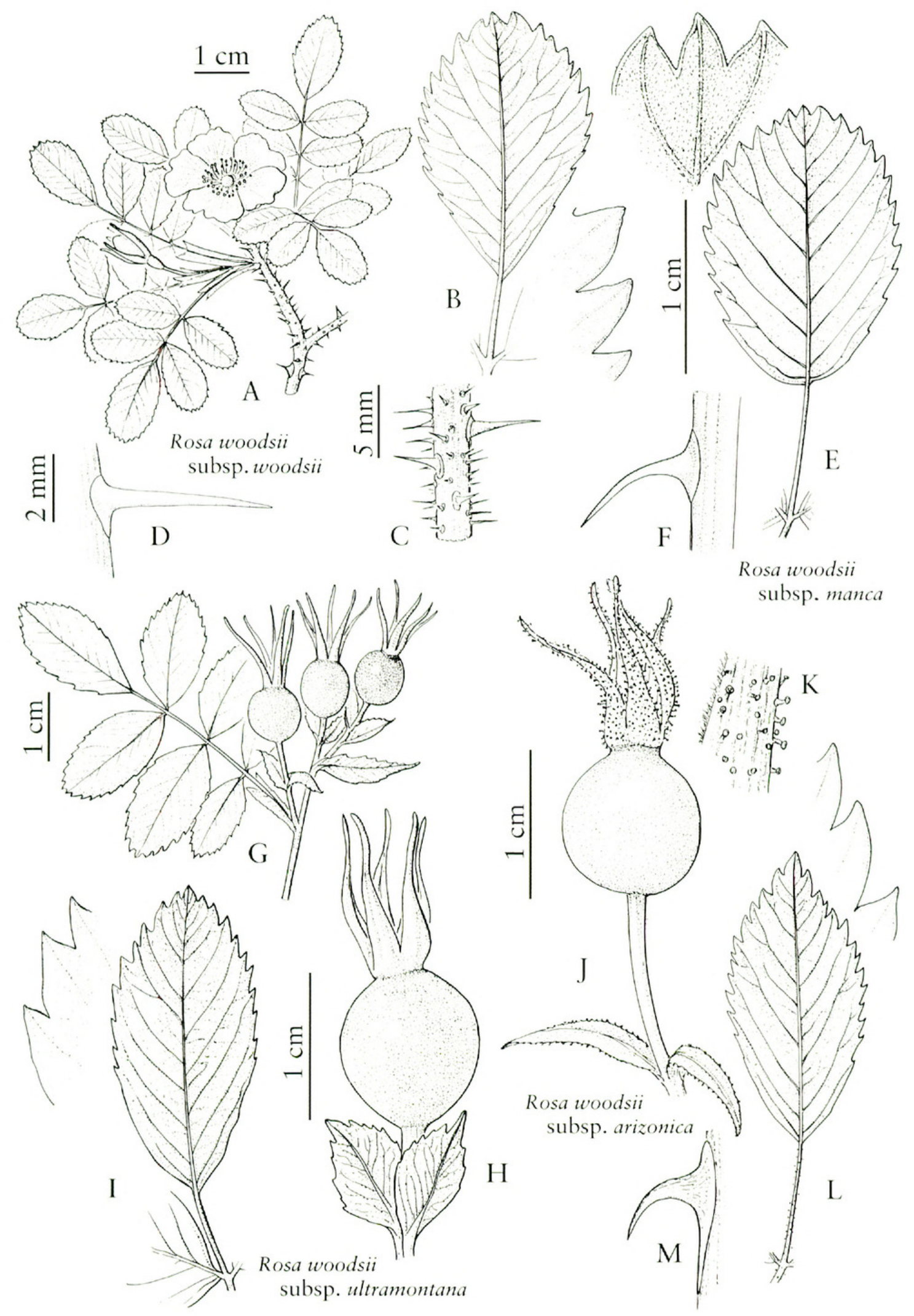

Figure 2. Rosa woodsii Lindley subspecies. A-D. Subspecies woodsii. - A. Flowering branch. - B. Terminal leaflet with serrations. - C. Varying prickles of branch. -D. Straight prickle. E-F. Subspecies manca (Greene) W. H. Lewis \& Ertter. -E. Terminal leaflet with serrations. - F. Curved prickle single or paired. G-I. Subspecies ultramontana (S. Watson) R. L. Taylor \& MacBryde. - G. Fruiting branch. - H. Hip with sepals and bracts. - I. Terminal leaflet with serrations. J-M. Subspecies arizonica (Rydberg) W. H. Lewis \& Ertter —J. Hip with sepals. - K. Enlarged sepal section showing stipitate glands. - L. Leaflet with serrations. - M. Hooked short prickle single or double. A-D drawn from Croutch 4 (MO); E-F drawn from Heil \& Vielly 19938 (SJNM); G-I drawn from Garrell 4099 (MO); J-M drawn from Ertter 18487 (MO); all by J. Myers. 
remains an invalid name. Similarly, another variety of theirs, R. woodsia var. hypoleuca (Wooten \& Standley) W. C. Martin \& C. R. Hutchins (1980: 928), is also invalid because it lacks a cited basionym.

As both the Maximilian and Martius herbaria are well represented in Crépin's herbarium at BR, the specimen there identified as Rosa maximiliani is chosen lectotype, as no other original collection has been located.

Rosa subnuda flowering material, Lunell 594 (25 June $1911[\mathrm{fl}])$, is selected lectotype because the syntype (14 Aug. 1911 [fr]) has not been found.

Rosa woodsii subsp. woodsii occurs in the prairies and high plains, often in woodland or riparian habitats, of central Canada and the United States from east-central Alaska, southern Yukon, and the Northwest Territory, south to northeastern British Columbia, and east to Manitoba; it is rare to western Ontario and Wisconsin, south to western Iowa, northwestern Oklahoma, western Texas, and west to New Mexico and eastern Arizona, and also extends into the passes of the Rocky Mountains from Montana to Colorado.

2b. Rosa woodsii Lindley subsp. ultramontana (S. Watson) R. L. Taylor \& MacBryde, Canad. J. Bot. 56: 189. 1978. Basionym: Rosa californica Chamisso \& Schlechtendal var. ultramontana S. Watson in W. H. Brewer \& S. Watson, Fl. Calif. 1: 187. 1876. Rosa ultramontana (S. Watson) A. Heller, Muhlenbergia 1: 107. 1904. Rosa woodsii var. ultramontana (S. Watson) Jepson, Fl. Calif. 2: 210. 1936. Rosa pisocarpa var. ultramontana (S. Watson) M. Peck (as "transmontana"), Man. Higher Pl. Oregon 404. 1941. TYPE: U.S.A. Nevada: Elko Co., East Humboldt Mtns. (= Ruby Mtns.), $2134 \mathrm{~m}$ (7000 ft.), July 1868, S. Watson 349 (lectotype, designated here, GH 244258). Figure 2G-I.

Rosa chrysocarpa Rydberg, Bull. Torrey Bot. Club 44: 74 . 1917. TYPE: U.S.A. Utah: San Juan Co., Allen Cañon, SW of Abajo Mtn., 1800-2000 m, 30-31 July 1911, P. A. Rydberg \& A. O. Garrell 9302 (holotype, NY 415920; isotype, US 765208).

Rosa grosseserrata E. E. Nelson, Bot. Gaz. 30: 119. 1900 (as "grosse-serrata"). TYPE: U.S.A. Wyoming: Madison River, Yellowstone Park, 30 Aug. 1899, A. Nelson \& E. W. Nelson 6787 (holotype, RM 20282; isotypes, MO 1798950, NY 415843, P, RM 156216).

Rosa lapwaiensis H. St. John, Fl. Southeast Wash. \& Idaho, 208. 1937. TYPE: U.S.A. Idaho: Nez Perce Co., Spalding, flat by Lapwai Creek, 27 May 1928, H. St. John, W. W. Eggleston, C. English \& G. N. Jones 9538 (holotype, WS 64725; isotypes, GH 32584, MIN 332733, NY 415848, RM 143193, UC 544891, US 1654700 , WS $64381 \& 64382$ ).
Rosa pyrifera Rydberg, Fl. Rocky Mts. 445, 1062. 1917. TYPE: U.S.A. Idaho: Bonner Co., shores of Lake Pend d'Oreille, near Lake View, 7 Aug. 1892, J. H. Sandberg, D. T. MacDougal \& A. A. Heller 871 (holotype, NY 415877; isotypes, K, MIN 258201, US 239145).

Rosa rotundata Rydberg, Bull. Torrey Bot. Club 44: 76. 1917. Syn. nov. TYPE: U.S.A. Nevada: Washoe Co., mtns. W of Franktown, 1737 m, 2 July 1912, A. A. Heller 10520 (holotype, NY 335708; isotypes, DS 12495, GH 32615 \& 61910, US 509790).

Rosa salictorum Rydberg, Bull. Torrey Bot. Club 44: 77. 1917. TYPE: U.S.A. Nevada: Nevada Co., Gold Creek, 1920 m, 25 July 1912, A. Nelson \& J. F. Macbride 2113 [often only J. F. Macbride] (holotype, NY 415880; isotypes, DS 252551, GH 32617, MO 1035641, NY 415881, POM 190661, RM 76160 \& 132364, UC 500427).

The original description of Rosa californica var. ultramontana did not cite collections and noted only that the variety is "on the eastern side of the Sierra Nevada, ranging to the Rocky Mountains." The inclusion of " $R$. blanda, Watson, Bot. King Exp. 91, and others" in his protologue, however, is an indirect reference to King Expedition 349, which is the number cited for $R$. blanda in the botanical report of the U.S. Geological Exploration of the Fortieth Parallel (Watson, 1871). As noted by Tiehm (1985), expedition numbers in this report were assigned to all collections believed to be the same taxon, often from multiple localities, and were primarily distributed among GH, NY, US, and YU. Although Tiehm recommends that taxa described by Watson be lectotypified on specimens at US, since this is where Watson was based while preparing the King Expedition report, the GH specimen of Watson 349 collected by Watson in East Humboldt Mountains is selected as lectotype, because Watson was at Harvard University while preparing the Botany of California. The designated lectotype is an excellent representative specimen, with both flowers and developing fruit, and is annotated as $R$. californica var. ultramontana in Watson's hand. Syntypes of Watson 349 include Unionville [Valley] (Pershing Co., NV), June 1868, S. Watson (NY 415919, US 65169, YU not seen), Humboldt Mountains (Elko Co., NV), Sept. 1868, S. Watson (NY 415918), and Truckee Valley (Washoe Co., NV), July 1867, W. W. Bailey (GH 244259, US 65170). The Bailey collection at $\mathrm{GH}$ is mounted on the same sheet with the lectotype, along with a collection by C. L. Anderson from Carson City, Nevada Territory, 1863 (GH 244263). The Anderson collection, and possibly numerous others, also qualifies as a syntype, given Watson's blanket reference to "and others" in his protologue. 
Rosa woodsii subsp. ultramontana occurs from central British Columbia east to Idaho, westem Wyoming, and probably also western Montana, south to California east of the Cascade Mountains, and Utah, Nevada, and infrequently as disjunct populations in Arizona and New Mexico. It is the commonest rose of this largely intermontane region that includes the Great Basin in western North America.

2c. Rosa woodsii Lindley subsp. arizonica (Rydberg) W. H. Lewis \& Ertter, comb. el stat. nov. Basionym: Rosa arizonica Rydberg, N. Amer. Fl. 22: 516. 1918. TYPE: U.S.A. Arizona: Coconino Co., vic. of Flagstaff, 2134 m, 15 June 1898, D. T. Macdougal 110 (holotype, NY 4.15909; isotypes, F 69856, GH 32554, NY 415910, RM 31869, UC 136507, US 334205). Figure 2J-M.

Rosa adenosepala Wooton \& Standley, Contr. U.S. Natl. Herb. 16: 131. 1913. Syn. nov. TYPE: U.S.A. New Mexico: San Miguel Co., along Pecos River, 8 mi. E of Glorietta, $1950 \mathrm{~m}, 9$ June 1897, A. A. Heller \& E. G. Heller 3674 (holotype, US 306499; isotypes, DAO 704029, MIN 130468, MO 1951202, P).

Rosa bakeri Rydberg, Fl. Colorado 191. 1906, nom. illeg.. non Rosa bakeri A. Déséglise, J. Bol. 2: 267. 1864. Syn. nov. TYPL: U.S.A. Colorado: La Plata Co., Dix Post Office, 1898, C. F. Baker, F. S. Earle \& S. M. Tracy 174 (lectolype, designaled here, MO 123806; isolypes. NO 1951244, NY).

Rosa granulifera Rydberg. N. Amer. Fl. 22: 517. 1918. Syn. nov. Rosa arizonica var. gramulifera (Rydberg) Kearney \& Peebles, J. Wash. Acad. Sci. 29: 481. 1939. TYPE: U.S.A. Arizona: Navajo Co., W of Holbrook, 10 July 1896, M. Zuck s.n. (holotype, NY 415841; isotypes, MO 123818. NY 415840. US 348991).

Rosa neomexicana Cockerell. Entomol. News 12: 38. 1901. Syn. nov. TYPLE: U.S.A. New Mexico: Otero Co.. Sacramento Mtns., Clouderofi, grown and collected at Mesilla, New Mexico, 4 May 1894, T. D. A. Cockerell s.n. (lectolype, designated here, US 404918; isotype, NY 425856$)$.

Rosa puberulenta Rydberg. Fl. Rocky Mts. 413, 1062. 1917. Syn. nov. TYPE: U.S.A. Utah: San Juan Co., Montezuma Canyon, E of Monticello, $2000 \mathrm{~m}, 13$ Aug. 1911, P. A. Rydberg \& A. O. Garretl 9705 (holotype. NY 415876; isotype, Us 765307).

Martin and Hutchins (1980: 930) reduced Rosa arizonica to a variety of $R$. woodsii, but as the basionym was not provided, it remains an invalid name. An additional two varieties of theirs, R. woodsii var. adenosepala (Wooten \& Standley) W. C. Martin \& C. R. Hutchins (1980: 929) and R. arizonica var. granulifera (Rydberg) W. C. Martin \& C. R. Hutchins (1980: 928), are also invalid, lacking provision of basionym.

Tiehm (1989) provided evidence to support the valid publication of Rosa bakeri and also $R$. pandorana Greene (see R. nutkana subsp. melina) found in Rydberg's Flora of Colorado (1906: 191). Rydberg provided no descriptions for these, nor for 26 additional new names, but since he used excellent keys to separate species, Tiehm believed that they were distinguishable and so satisfied the provisions of Article 32.2. However, Rydberg gave no collectors for localities he listed; fortunately, locality descriptions of Rosa are sufficiently unique to associate collectors with localities using material at NY, MO, US, and other herbaria. He provided R. bakeri with four syntypes. Tiehm suggested that holotypes or lectotypes be selected from collections he listed in his paper, although he clearly stated that he was not designating lectolypes. The latter is fortunate with regard to R. bakeri, for Tiehm's choice of Batier s.n. (U.S.A. Colorado: Routt Co., Four-miles Hill, 2 July 1896) would have been inappropriate since Rydberg (1904: 561) had already used this collection as holotype of $R$. oreophila (see $R$. nutkana subsp. melina). The lectotype selected above (Batier et al. 474 ) is appropriate diagnostic material that clearly delineates between $R$. mutkana and R. roodsii, which Rydberg often confused, and since the specific epithet honors Baker as collector, it seems appropriate to select a syntype collected by him. Unfortunately, the $R$. oreophila sheet at NY (4.15860) is annotated with two holotype labels, one for $R$. oreophila, which the specimen clearly represents $(=R$. nutkana subsp. melina), and the other for R. bakeri, which it certainly does not. In this instance, the lectotype is chosen from one of two sheets of Bater et al. 474 at MO (123806), where no ambiguity of identity or typification exists and where Rydberg wrote and initialed "Rosa bakeri" on the sheet and later stamped by his writing "OK Dr. Rydberg Sep. 1911.”

With regard to lectotypification of Rosa neomexicana, Cockerell did not select a type from several collections he and/or E. O. Wooton gathered at Cloudcroft, New Mexico, or from those then cultivated at Mesilla, New Mexico, nor did he indicate a herbarium of deposit, so a lectotype appropriate to his diagnosis was chosen at US with an isolectotype at NY. Martin and Hutchins (1980: 929) reduced $R$. neomexicana to a variety of $R$. woodsii, but as the basionym was not provided, it remains an invalid name.

Rosa woodsii subsp. arizonica occurs in Arizona, western Colorado, southwestern Nevada, New Mexico, and Utah at elevalions ranging from ca. 1400 to $2200 \mathrm{~m}$, with a possible disjunction in southern Idaho. It is most frequent in Arizona and southem Utah and as such is associated with the southem Colorado Plateau Floristic Element (McLaughlin. 1989) in North America. 
Selected exsiccatae. U.S.A. Arizona: Apache Co., White Mtns., $10 \mathrm{mi}$. S of Black River, $1830 \mathrm{~m}, 22$ June 1930, G. J. Goodman \& C. L. Hitchcock 1296 (MO); Cochise Co., Chiricahua Mtns., Stephens' ranch, $1830 \mathrm{~m}$, Oct. 1906, J. C. Blumer 1240 (US); Coconino Co., Oak Creek Canyon, 9 mi. $\mathrm{N}$ of Sedona, $1620 \mathrm{~m}$, I July 1992, J. S. Miller et al. 7746 (MO); rd. to Inner Basin on E side of San Francisco Mtns., 17 Aug. 2004, B. Ertter et al. 18484 (MO, UC); Mohave Co.. Wild Cow Spring, Hualapai Mtns. SE of Kingman, 13 Aug. 2004, B. Ertter 18489 (with L. Woodruff) (MO, UC); Yavapai Co., Prescoll, 14 Aug. 1932, G. J. Harrison, T. H. Kearney \& R. H. Peebles 8885 (POM, UC). Nevada: Clark Co., Charleston Park, Charleston Mtns., 8 Aug. 1937, I. W. Clokey 7788 (POM, UC); Hidden Forest, Sheep Mtns., 10 June 1940, A. M. Alexander \& L. Kellogg 1701 (UC). New Mexico: Grant Co., Mangus Springs, along streams, 30 May 1881, H. H. Rusby 129 1/2 (MO); San Juan Co., San Juan River, Jewett Valley Tract, 1710 m, 18 June 1997. T. Reeves \& L. Reeves 9418 (SJNM). Utah: Duchesne Co., 4 mi. $\mathrm{N}$ of Mountain Home, 2135 m, 13 June 1934, B. F. Harrison \& E. Larson 7592 (MO); Kane Co., W of Coral Pink Dunes, vic. of Pine Spring, ca. 1700 m, 29 May 1992, S. L. Welsh 25005 (MO); San Juan Co., Montezuma Canyon, ca. 13 air mi. SSE of Monticello, ca. 1720 m, 19 Aug. 2004, B. Ertter 18480 (with L. Woodruff) (MO, UC); Navajo Nation, ca. 2 mi. SE of Blanding, 1720 m, 21 June 2004, K. Heil et al. 24062 (MO. SJNM); Washington Co., SE of Enterprise Reservoir, $1780 \mathrm{~m}$. 18 June 1998, L. Higgins 19725 (MO).

2d. Rosa woodsii Lindley subsp. manca (Greene) W. H. Lewis \& Ertter, comb. et stat. nov. Basionym: Rosa manca Greene, Pittonia 4: 11. 1899. TYPE: U.S.A. Colorado: Montezuma Co., Upper West Mancos Cañon, $2750 \mathrm{~m}, 3$ July 1898, C. F. Baker, F. S. Earle \& S. M. Tracy 31.3 (holotype, NDG 23545; isotypes, F $76117 \&$ 356377, GH 32587, K, MO 123823, NO, NY 415852 \& 415853 , RM 13646 \& 156323, US 337232 ). Figure 2E-F.

Rosa woodsii subsp. manca occurs in the high mountains of Arizona, Colorado, New Mexico, Utah,

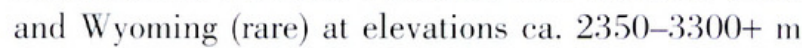
within the Southern Rocky Mountain-Mogollon Floristic Element (McLaughlin, 1986, 1989) in North America. It is not the R. manca sensu Erlanson (1934: 230 ), which is described as a hexaploid ecotype species of $R$. nutkana (= subsp. melina).

Selected exsiccatae. U.S.A. Arizona: Apache Co.. LukaChukai Mtns. 2800 m, 4 July 1936, G. J. Goodman \& L. B. Payson 2926 (MO); Coconino Co., Kendrick Peak along trail 22, 3050 m, 5 Aug. 1983, J. Ricketson 570 (MO). Colorado: Archuleta Co., along Piedra River trail, 2990 m, 30 June 1999, K. Heil et al. 13435 (SJNM); Gunnison Co., Gothic, N of Judd Falls along Copper Creek, 2990-3050 m, 26 July 1977, L. J. Dorr 602 (MO); Mineral Co., 0.3 mi. from jet. of hwy. 160 \& Tucker Ponds rd., 2830 m, 21 July 2005, W. H. Lewis \& M. Elvin-Lewis 21005 (MO, UC); Montrose Co., Uncompahgre Plateau, 19 air mi. SW of Montrose, $2965 \mathrm{~m}, 7$ Aug. 2004, B. Ertter et al. 18463 (MO, UC); Ouray Co., SE of
Ouray, 2300-2600 m, 7 Sep. 1901, L. M. Underwood \& A. D. Selby 63 (NY); Summit Co., Lake Dillon, near jct. of hwys. 170 \& 6, 2800 m, 9 July 1985, W. H. Lewis 9828 (MO), 9829 (MO). New Mexico: McKinley Co., Navajo Nation, ca. 12.5 mi. Lurning SE of Whiskey Lake rd., 2685 m, 15 Sep. 2004, K. Heil \& W. Mietty 24937 (MO, SJNM); San Miguel Co., Sangre de Cristo Mtns., valley of Gallinas River, 25902745 m, 11-17 Aug. 1945, C. L. Lundell \& A. A. Lundell 14478 (MO); Taos Co., Carson Natl. Forest, ca. 8 mi. NW of Mora, 2750 m, 1 July 1998, H. H. Schmidt et al. 2727 (MO); Forestry rd. 537 from Red River to Cabresto Canyon, 2440-2775 m, 17 June 2006, H. van der Werff 21523 (MO). Utah: San Juan Co., N slope of Abajo Mtns., 2590-3355 m, 1-2 July 1930, G. J. Goodman \& C. L. Hitchcock 1424 (F); Navajo Nation, Navajo Mtn., just E of War God Spring, 2608 m, 7 July 2001, S. L. O'Kane Jr. et al. 5797 (SJNM); Uinta Co., Uinta Basin, Taylor Mtn., Davis Hollow, 2655 m, 7 Sep. 1931, E. H. Graham 7492 (MO); Washington Co., Markagunt Plateau, ca. $1.6 \mathrm{~km} \mathrm{~N}$ of Kolob Reservoir, $2500 \mathrm{~m}, 7$ July 1984, N. H. Holmgren \& P. K. Holmgren 10591 (NY, UT). Wyoming: Sweetwater Co., S side of Cedar Mtns., 2440 m, 7 July 1981, R. W. Lichvar $4574(\mathrm{NY})$.

2e. Rosa woodsii Lindley subsp. gratissima (Greene) W. H. Lewis \& Ertter, stat. nov. Basionym: Rosa gratissima Greene, Fl. Francisc. 1: 73. 1891. Rosa pisocarpa var. gratissima (Greene) Jepson, Man. Fl. Pl. Calif. 499. 1925. Rosa woodsii var. gratissima (Greene) D. Cole, Amer. Midl. Naturalist 55: 223. 1956. Syn. nov. TYPE: U.S.A. California: Kern Co., near Tehachapi, mtns. by wet meadows, 24 June 1889, E. L. Greene s.n. (holotype, NDG 23620; isotype, NY 4.15842).

Rosa woodsii subsp. gratissima occurs in springs and along streams in the mountains in and surrounding the Mojave Desert and southern Great Basin, from the east side of the Sierra Nevada in Mono County, California, east to Eureka County in central Nevada, and south to the Nevada Test Site in Nye County and the north slope of the San Bernardino Mountains, San Gabriel Mountains, and Mount Pinos in southern California. This is also the characteristic subspecies in the southern Sierra Nevada from Fresno County southward, and populations occur in the White Mountains on the California-Nevada border and the Panamint Mountains west of Death Valley.

Selected exsiccatae. U.S.A. California: Fresno Co., Doris Lake, 1 mi. N of High Sierra Pack Station at Mono Hot Springs on S Fork San Joaquin River N of Kaiser Ridge, 27 Aug. 1959, C. H. Quibell 3389 (RSA, UC); Inyo Co., Thorndykes Springs, Wildrose Canyon, Panamint Mins., 12 July 1947, J. C. Roos 2837 (RSA); Big Pine Creek at foot of trail to Big Pine Lakes, 26 July 1934, R. S. Ferris 9009 (DS, UC); Kern Co., 3 mi. E of monolith, [s.d.], M. Zigmond 713 (POM); Los Angeles Co., Prairie Fork of San Gabriel River, 
23 Aug. 1917, I. M. Johnston 1704 (RSA, UC); Mono Co.. 2 mi. SE of Hardy Station, 11 Sep. 1936, W. A. Peterson 593 (UC); San Bernardino Co., 2 mi. along Mill Creek Rd. and 2N10 from Coldbrook Campgound, San Bernardino Mtns., 15 July 1976, R. F. Thorne, L. DeBuhr, C. Davidson \& C. W. Tilforth 47723 (RSA, UC); Tulare Co., S branch of Monache Creek, near S fork of Kern River, 24 July 1950, P. A. Munz 15349 (RSA); Ventura Co., Seymour Meadows, Mt. Pinos, 11 July 1905, H. M. Hall 6624 (UC). Nevada: Clark Co., Indian Springs, base of NE slope of Spring Mtns., $1860 \mathrm{~m}$, I June 1970, J. Bealley \& J. L. Reveal 10822 (MO); Esmeralda Co., 1 mi. E of Lida, 9 Aug. 1928, C. B. Wolf 3218 (RSA); Trail Canyon, White Mtns., I July 1931, V. Duran 3089 (POM, UC); Eureka Co., vic. of the Willows, ca. 34 mi. W of Eureka, 5 July 1937, F. S. Goodner \& W H. Henning 572 (POM); Lincoln Co., Bald Mtn. Spring, Timpahute Range, 2000 m, 2 July 1968, J. L. Reveal \& J. C. Bealley 1451 (MO); Lander Co., Smith's Creek Canyon, $44 \mathrm{mi}$. W of Austin, 10 July 1937, F. S. Goodner \& W. H. Henning 655 (MO); Nye Co., along wash below Cliff Spring, Belted Range, Nevada Test Site, 8 June 1969, J. Bealley \& H. Kaaz 8890 (RSA); Thirsly Canyon, Rose Creek, 1830 m, 27 July 1967, J. Beatley \& W. H. Rhoads 4547 (MO).

\section{2e1. Rosa woodsii Lindley var. glabrata (Parish)} D. Cole, Amer. Midl. Naturalist 55: 223. 1956, non Rosa glabrata P. Kitaibel in A. Kanitz, Linnaea 32: 588. 1863. Rosa californica Chamisso \& Schlechtendal var. glabrata Parish, Erythea 6: 88. 1898. Rosa mohavensis Parish, Bull. Soc. S. Calif. 1: 87. 1902. Rosa woodsii var. mohavensis (Parish) Jepson, Fl. Calif. 2: 210. 1936, nom. illeg., earlier name available at rank. TYPE: U.S.A. California: San Bernardino Co., desert side of San Bernardino Mtns., Cushenberry Spring, 1200 m, I June 1892, S. B. Parish 2481 (holotype, DS; isotype, GH).

Localized clusters of glabrous populations on the north foot of the San Bernardino Mountains represent the variety glabrata within Rosa woodsii subsp. gratissima.

Selected exsiccatae. U.S.A. California: San Bernardino Co., Box "S" Springs, Mojave Desert, 28 Apr. 1926, H. L. Mason 3090 (GH, UC); 2 mi. W of Cushenberry Springs, 975 m, 9 Oct. 1937, P. A. Munz \& F. Youngberg 14962 (MO).

Acknowledgments. The authors thank James L. Reveal and C. Rose Broome for herbarium and living collections from westem Colorado, Henk van der Werff for collections from northern New Mexico, and Memory Elvin-Lewis and Lindsay Woodruff for support in the field. Special appreciation goes to the WS group (Larry Hufford, Joy Mastroguiseppe, and Joshua Brokaw), RM (Ronald Hartman), GH (Emily Wood and Melinda Peters), and US (Rusty Russell) for providing digital images of types, and the directors, curators, and managers of herbaria at A, ASC, BM, BR, CAN, CAS, CGE, CIC, CU, DAO, DS, E, GH, JEPS, K, LE, MIN, MO, MT, NDG, NO, NY, P, PH, POM, PR, RSA, SASK, SJNM, SPR, UC, US, UTC, WTU, and YU, who organized loans, made digital image databases available, made research visits to use their collections possible, and assisted in other ways. Support to Barbara Ertter from the Lawrence R. Heckard Endowment Fund of the Jepson Herbarium is gratefully acknowledged. We are indebted to staffs of the Jeanette Goldfarb Plant Growth Facility, Department of Biology, Washington University, and the University of California Botanical Garden for assistance with living collections. Our reviewers, Roy Gereau and Robert J. O'Kennon, and editor Victoria Hollowell provided most helpful guidance and suggestions for improving the manuscript. We also thank John Myers at MO for his fine line drawings of both species.

\section{Lilerature Ciled}

Crépin, F. 1876. Primitiae Monographiae Rosarum. XII. Prodrome d'une Monographie des Roses Américaines. Bull. Soc. Roy. Bot. Belgique 15: 12-98.

Erlanson, E. W. 1934. Experimental data for a revision of the North American wild roses. Bot. Gaz. 96: 197-259.

Kolb, K. J. \& J. S. Sperry. 1999. Differences in droughı adaptation between subspecies of sagebrush (Artemisia tridentata). Ecology 80: 2373-2384.

Lewis, W. H. 1980. Polypoidy in species populations. Pp. 103-147 in W. H. Lewis (editor), Polyploidy: Biological Relevence. Plenum Press, New York.

Lyall, D. 1863. Account of the botanical collections made by David Lyall Surgeon and Naturalist to the North American Boundary Commission. J. Proc. Linn. Soc. London, Bot. 7: $124-144$.

Martin, W. C. \& C. R. Hutchins. 1980-81. A Flora of New Mexico, Vol. 1 (1980), Vol. 2 (1981). J. Cramer, Braunschweig, West Germany.

Mclaughlin, S. P. 1986. Floristic analysis of the southwestern United States. Great Basin Naturalist 46: 46-65.

1989. Natural floristic areas of the western United States. J. Biogeogr. 16: 239-248.

Piper, C. V. 1906. Flora of the State of Washington. Contr. U.S. Nall. Herb. 11: 1-637.

Rydberg, P. A. 1904. Studies on the Rocky Mountain Flora XII. Bull. Torrey Bot. Club 31: 555-575.

1906. Flora of Colorado. Bull. 100, Agricultural Experiment Station of the Colorado Agricultural College, Fort Collins, Colorado.

- 1918. Rosa. North American Flora 22: 483-533.

Schultz, L. A. 2006. Artemisia. Pp. 503-534 in Flora of North America Editorial Committee (editors), Flora of North America North of Mexico, Vol. 19. Oxford Univ. Press, New York.

Taylor, R. L. \& B. MacBryde. 1978. New taxa and nomenclatural changes with respect to vascular plants of British Columbia: A Descriptive Resource Inventory. Canad. J. Bot. 56: 184-195. 
Tiehm, A. 1985. Vascular plant types of Clarence King's exploration of the fortieth parallel, 1867-1869. Brittonia 37: 400-424.

. 1989. Vascular plants first described in Rydberg's Flora of Colorado. Brittonia 41: 152-155.
Torrey, J. \& A. Gray. 1840. A Flora of North America 1: $457-462$.

Watson, S. 1871. Botany. In C. King (editor), Report U.S. geological exploration of the fortieth parallel 5: 1-525, Government Printing Office, Washington. 


\section{$2 \mathrm{BHL}$ Biodiversity Heritage Library}

Ertter, Barbara Jean and Lewis, W H. 2007. "Subspecies of Rosa nutkana and R. woodsii (Rosaceae) in western North America." Novon a journal of botanical nomenclature from the Missouri Botanical Garden 17, 341-353. https://doi.org/10.3417/1055-3177(2007)17[341:SORNAR]2.0.CO;2.

View This Item Online: $\underline{\text { https://www.biodiversitylibrary.org/item/41805 }}$

DOI: https://doi.org/10.3417/1055-3177(2007)17[341:SORNAR]2.0.CO;2

Permalink: https://www.biodiversitylibrary.org/partpdf/17563

\section{Holding Institution}

Missouri Botanical Garden, Peter H. Raven Library

\section{Sponsored by}

Missouri Botanical Garden

\section{Copyright \& Reuse}

Copyright Status: In copyright. Digitized with the permission of the rights holder.

License: http://creativecommons.org/licenses/by-nc-sa/3.0/

Rights: https://biodiversitylibrary.org/permissions

This document was created from content at the Biodiversity Heritage Library, the world's largest open access digital library for biodiversity literature and archives. Visit BHL at https://www.biodiversitylibrary.org. 